\title{
Analysis of Air-Cooling Battery Thermal Management System for Formula Student Car
}

\author{
Leone Martellucci, Kodekondla Kalyan Krishna \\ Department of Astronautical, Electrical and Energy Engineering, Sapienza University, Rome, Italy \\ Email: leone.martellucci@uniroma1.it, kalyankrishna1996@gmail.com
}

How to cite this paper: Martellucci, L. and Krishna, K.K. (2021) Analysis of Air-Cooling Battery Thermal Management System for Formula Student Car. Journal of Transportation Technologies, 11, 436-454. https://doi.org/10.4236/jtts.2021.113029

Received: May 14, 2021

Accepted: July 25, 2021

Published: July 28, 2021

Copyright $\odot 2021$ by author(s) and Scientific Research Publishing Inc. This work is licensed under the Creative Commons Attribution International License (CC BY 4.0).

http://creativecommons.org/licenses/by/4.0/

\section{(c) (i) Open Access}

\begin{abstract}
Designing a good energy storage system represents the most important challenge for spreading over a large scale of electric mobility. Proper thermal management is critical and guarantees optimum working temperature in a battery pack. In the various battery thermal management technologies, air cooling is one of the most used solutions. The following work analyzes the cooling performance of the air-cooling thermal management system by choosing appropriate system parameters and analyzes using CFD simulations for accurate thermal modeling. These parameters include the influence of airflow rate and cell spacing on the configuration. The outcome of the simulations is compared using parameters like maximum temperature, and temperature distribution in the battery module to obtain optimum results for further applications. Finally, the simulations of the optimal solution will be compared to experimental results for validation.
\end{abstract}

\section{Keywords}

Battery, Thermal Management System, Air-Cooling, Formula Student

\section{Introduction}

\subsection{Li-Ion Batteries}

The portable power supply has become the lifeline of the modern technological world, especially lithium-ion batteries. Current EVs and HEVs have significant requirements from the battery technologies as they include additional functionalities (such as power-assistance, regenerative braking, and electric auxiliaries) which cannot be easily satisfied with the most commonly used battery chemistries like $\mathrm{Pb}$-acid, NiCad, NiMH due to their relatively lower energy and power densities. On the other hand, Li-ion chemistry provides cells relatively lightweight with high volumetric and energy density, and it is mostly utilized in stationary 
and automotive applications. Today a wide range of Lithium-ion chemistries are available concerning the composition of their cathode; some of the widely used ones are $\mathrm{LiCoO}_{2}$ (LCO), $\mathrm{LiMn}_{2} \mathrm{O}_{4}(\mathrm{LMO}), \mathrm{LiFePO}_{4}$ (LFP), $\mathrm{LiNiMnCoO}_{2}(\mathrm{NMC})$, $\mathrm{LiNiCoAlO}{ }_{2}$ (NMA) and $\mathrm{Li}_{4} \mathrm{Ti}_{5} \mathrm{O}_{12}$ (LTO). Compare with the above chemistries, NMC has the highest energy density and the best market availability. From this advantage, we have considered this chemistry for this work and for the battery pack of the Sapienza University Formula Student car.

The form factor is another important characteristic; Li-ion batteries are manufactured in three different forms (see Figure 1):

Cylindrical cell-The electrochemical cell of the batteries consists of a layer of positive electrode (cathode), negative electrode (anode), electrode, and the separator. These layers are rolled up to make a jellyroll and wound onto the cylinder around a central steel core, thus, make a cell more compact.

Prismatic cell-These cells are similar in construction to cylindrical cells but use a flat rectangular housing to lower the overall thickness of the cell. Aluminum or steel cans are typically used as housing.

Pouch cell-The cells are contained with a soft plastic-aluminum package, with a typically thin foil form factor. Current collectors are welded internally to terminal tabs that protrude through seals to allow the external connection.

\subsection{Thermal Issues of Li-Ion Batteries}

Li-ion batteries produce heat during the charge and discharge operations and high temperature will decay the performance. The temperature of the cells must be strictly maintained within optimum working temperature range $15^{\circ} \mathrm{C}-45^{\circ} \mathrm{C}$ across the entire battery pack. Thermal issues like overheating and uneven temperature distribution can lead to rapid cell degradation and shorten battery life. In extreme cases, thermal runaway may also occur when the cell temperature rises above the limit, in which this high temperature triggers the exothermic reactions in the operating cells. These reactions release more heat led to an uncontrolled heat generation causes fire or explosion; this incident initiates at about $90^{\circ} \mathrm{C}$ when the SEI decomposes.

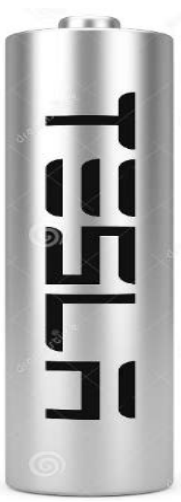

(a)

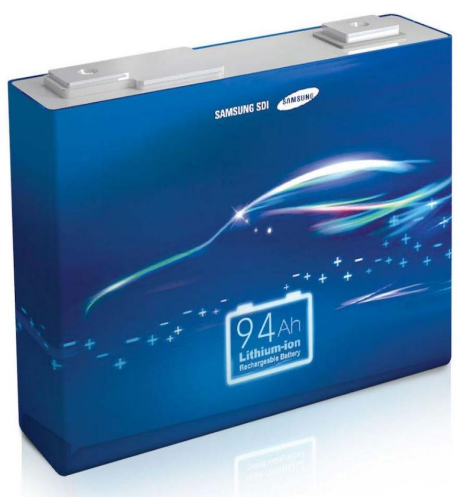

(b)

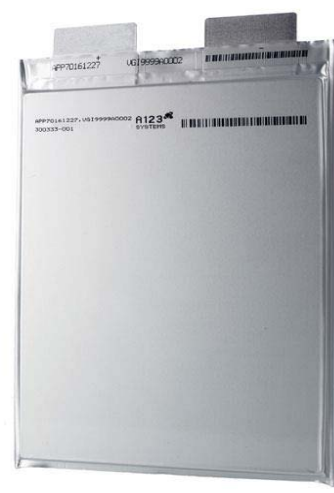

(c)

Figure 1. (a) Cylindrical cell; (b) Prismatic cell; (c) Pouch cell. 
Thus considering, one of the major concerns in the development of lithium-ion battery packs is thermal management. As we discussed above, thermal issues for the battery will give a negative impact on battery performance, lifespan, and safety of the batteries. The thermal management is required to solve these issues, and this system regulates the battery pack to operate in the desired temperature range $15^{\circ} \mathrm{C}-35^{\circ} \mathrm{C}$ for optimum performance/life, maintain an even temperature distribution, prevent uncontrolled temperatures (thermal runaway) in the battery pack. Voltage protection is another crucial job of the Battery Management System.

Similar to conventional ICE vehicles, a battery pack in EVs and HEVs need a cooling system. Different types of cooling system technologies will influence the performance and cost of the battery pack thermal management system.

\subsection{Thermal Management Technologies}

Over the last two decades, many battery thermal management technologies have been developed to maintain the optimum temperature range in the battery packs namely.

1) The Air-cooling method classifies into Natural \& Forced Convection;

2) The Liquid-cooling method classifies into Indirect \& Direct cooling;

3) Thermal storage method such as Phase Change Material;

4) The Heating method classifies into Self-internal heating, Convective heating, and Mutual Pulse heating.

Compared with the above technologies, the air and liquid cooling are most widely using methods to fulfill the requirements of automotive industries. This work intended to focus on the air-cooling method due to its simple structure, lower manufacturing cost, lighter, easier to maintain, and higher reliability of the system. However, the air has much smaller heat capacity than liquid, and thus a much higher volumetric flow rate is required to achieve the same cooling performance.

\subsection{Air-Cooling Method}

In the Air-cooling battery thermal management solution, the air is the cooling medium and removes the heat generated by the battery cell. This cooling method classified into Passive cooling (Natural convection) and Active cooling (Forced Convection) [1] [2] [3]. The former passive (only ambient environment used) typically used for low-density batteries, and the latter active (special components provide for heating or cooling at cold or hot temperatures) use fans/blowers to enhance convection [4] [5].

\section{Battery Pack}

The Formula Student electric car is equipped with a storage system placed is in the central part of the chassis, in backside position respect of the driver seat. The cockpit of the single-seater car and the battery pack are separated by the alumi- 
num and Kevlar fire retardant wall, which guarantees electrical insulation and segregation of flames in the event of breakdowns. The battery pack is made up by six modules connected in series, in an electrical configuration with string of 108 parallels of 7 cells, 108s7p configuration. Each module is a 18s7p assembly, with $75.6 \mathrm{~V}$ of maximum voltage and $1.58 \mathrm{kWh}$ of maximum stored energy. In Table 1 the whole battery pack specifications are reported and in Figure 2 and Figure 3 the cell specifications and performance graphs are reported. In Figure 4 and Figure 5 CAD drawing and photo of the battery pack are presented.

Table 1. Battery pack specifications.

\begin{tabular}{cc}
\hline Cell type & Cylindrical \\
Cell manufacturer & Sony \\
Cell model & US18650VTC6 \\
Electrical Configuration & $7 \mathrm{p} 108 \mathrm{~s}$ \\
Maximum Voltage $[\mathrm{V}]$ & 450 \\
Payable Energy $[\mathrm{kWh}]$ & 8.1 \\
Container Dimensions $[\mathrm{mm}]$ & $494 \times 463 \times 238$ \\
\hline
\end{tabular}

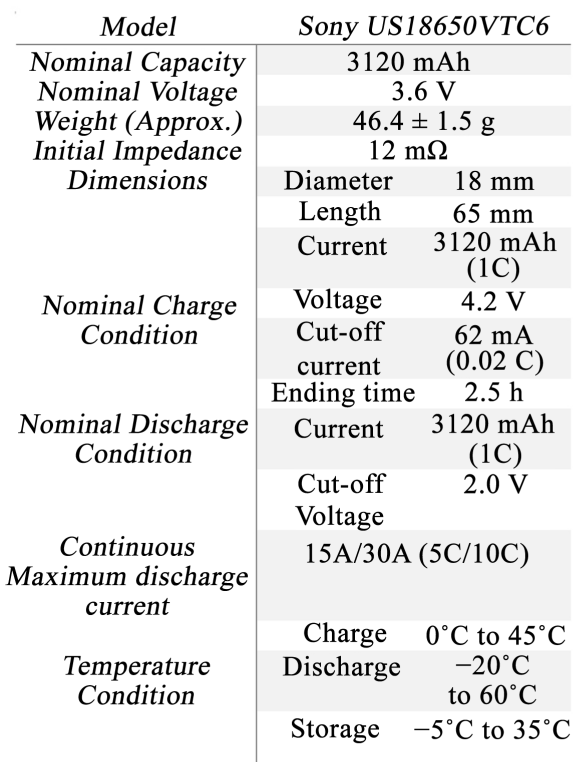

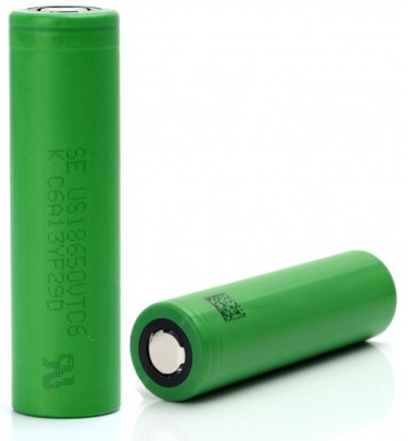

(b)

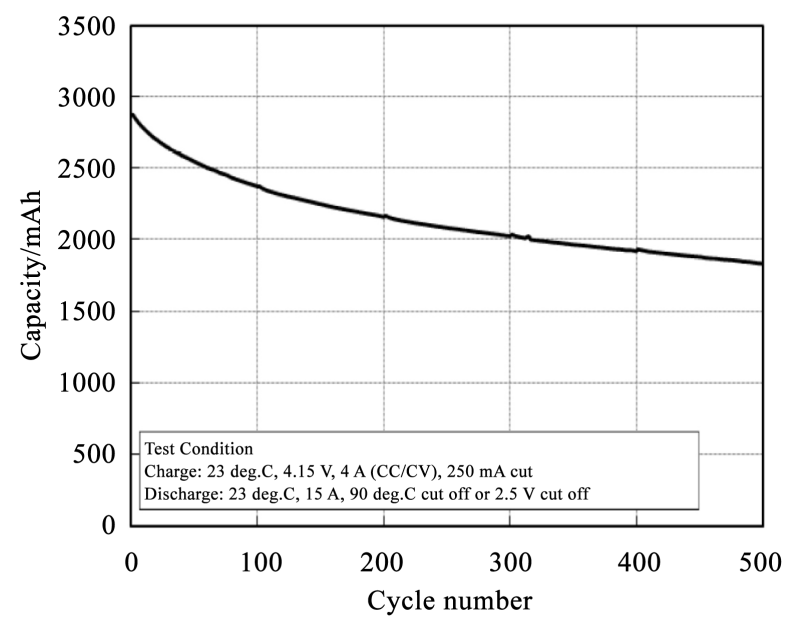

(c)

Figure 2. (a) Cell properties; (b) Cell model; (c) Cycle life. 


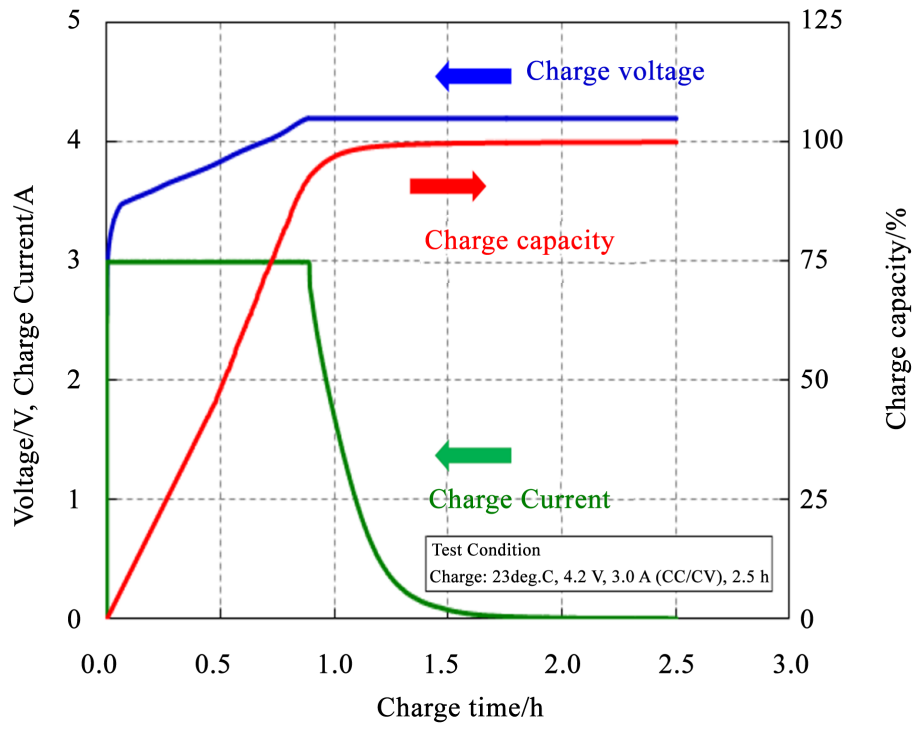

(a)

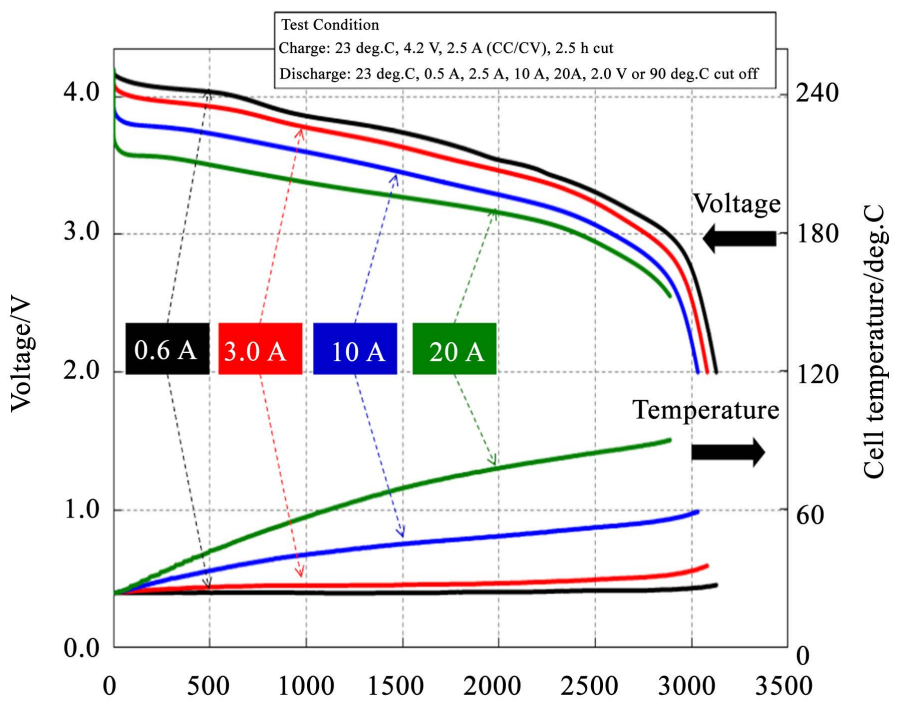

(b)

Figure 3. (a) Charge characteristics, (b) Discharge characteristics.

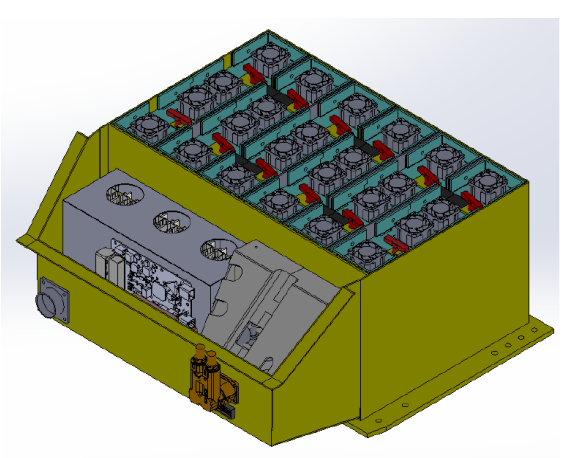

(a)

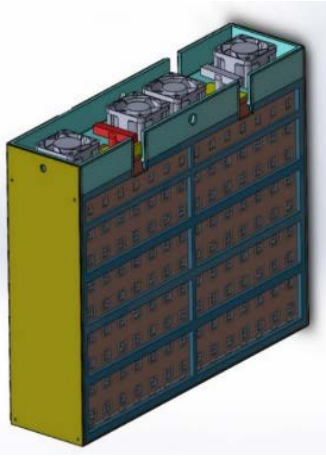

(b)

Figure 4. (a) Assembly of battery pack; (b) Assembly of battery module. 


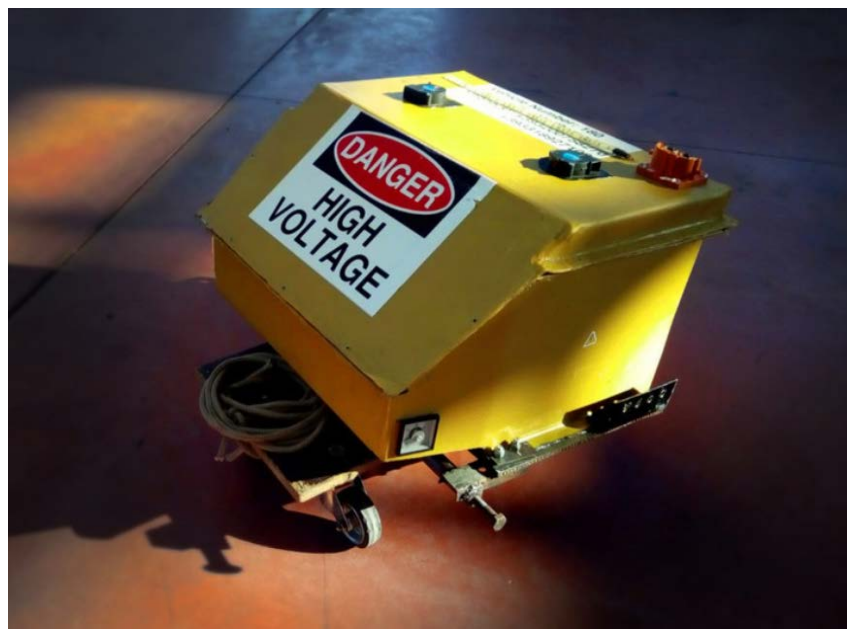

Figure 5. Battery pack of the vehicle.

\section{Methodology}

\subsection{Battery Module}

Initially, to perform CFD analysis on the Air-cooling battery thermal management solution method has been studied using ANSYS FLUENT software. Li-ion cells and battery module modelled in workbench. The battery module has 126 Cylindrical Li-ion cells of 18,650 format, positioned linearly in 9 rows of 14 each. And each battery cell has a diameter of $18 \mathrm{~mm}$ and a length of $65 \mathrm{~mm}$.

The thermal properties of single cell are reported in Table 2, where the most important parameters used for CFD thermal model are axial and radial thermal conductivities.

\subsection{Air-Cooling Methodology}

In this battery module configuration, there are two inlets and two outlets in which the air enters and exits through these sections (see Figure 6). When the air enters from the both the inlets, this flow is used to cool down the batteries arranged in series, so its temperature rises due to its low heat capacity, and this leads to higher cell temperatures at the pack outlet. For this, there are some significant measures were taken to improve the cooling performance in the module by increasing the cooling speed, optimizing the position of each cell arranged side by side in a rectangular pattern, and positioning fan on top of the battery module. Another important factor consideration, reciprocating airflow can significantly improve the thermal performance of the battery module. So, the configuration has both inlets and outlets are on the top where it can create the flow moving forward and backward.

\subsection{Heat Generation inside the Batteries}

Battery cooling is directly proportional to the heat generated inside the battery. The most common equation describing heat generation in a battery cell during an electrochemical process (charge or discharge) is given by Equation (1). 


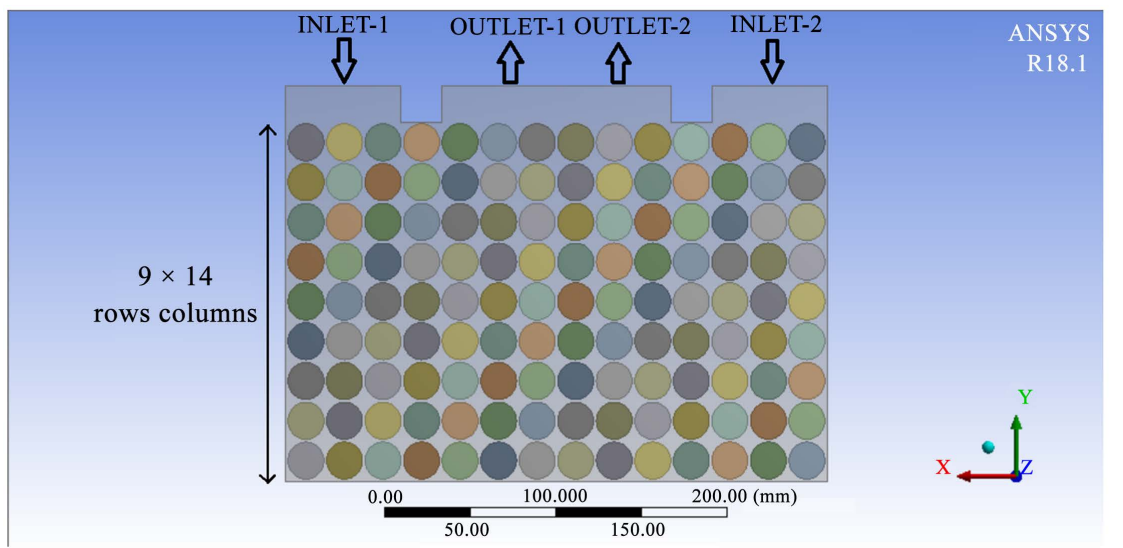

Figure 6. Battery module geometry.

Table 2. Sony VTC6 thermal properties.

\begin{tabular}{cc}
\hline Parameter & Value \\
\hline Diameter & $18 \mathrm{~mm}$ \\
Length & $65 \mathrm{~mm}$ \\
Weight & $47 \mathrm{~g}$ \\
Rated Discharge Capacity (1C-Rate) & $3.12 \mathrm{Ah}$ \\
Nominal Voltage & $3.6 \mathrm{~V}$ \\
Rated Discharge Energy & $11.1 \mathrm{Wh}$ \\
Density & $2800 \mathrm{Kg} / \mathrm{m}^{3}$ \\
Heat Capacity & $950 \mathrm{~J} /(\mathrm{Kg} \cdot \mathrm{K})$ \\
Radial thermal conductivity & $1 \mathrm{~W} /(\mathrm{m} \cdot \mathrm{K})$ \\
Axial thermal conductivity & $25 \mathrm{~W} /(\mathrm{m} \cdot \mathrm{K})$ \\
Internal Resistance & $30 \mathrm{~m}$ \\
\hline
\end{tabular}

$$
q=I\left(V_{o}-V\right)-I T\left(\frac{\mathrm{d} V_{o}}{\mathrm{~d} T}\right)
$$

where $q$ is the heat generation in the battery cell, $V_{o}$ is the open-circuit voltage, $V$ is the cell voltage, $I$ is the applied current and $T$ is the temperature of the cell.

From the Equation (1), the first term of the equation represents the overpotential due to the ohmic losses and charge transfer at the interface. The Second term represents the reversible entropic heat from the reaction [6] [7].

When a current flow in a battery, the cell voltage $V$ deviates from the open-circuit voltage $V_{o}$ because of electrochemical polarization. The resulting energy loss is converted into heat. This heat can be calculated using the internal resistance and current of the cell. The cells are assumed as a constant heat source.

This heat generation can be expressed as overpotential heat $Q$ :

$$
Q=I\left(V_{o}-V\right)=I^{2} R
$$

$Q$ represents heat generation during both charging and discharging. Express- 
ing the difference between $V$ and $V_{o}$ by $I R . R$ is the overpotential resistance related to $Q[8]$ [9].

If the heat generation rate per unit time and volume, the Equation (2) represents:

$$
Q=I^{2} R / V
$$

where $V$ is the effective calculating volume of the battery module. In Table 3 the single cell heat generation data are collected.

\subsection{C-Rate}

C-Rate is a relative measure performance of the battery [10]. Charge and discharge rates are governed by $\mathrm{C}$-rates. For instance, a $\mathrm{IC}$ discharge rate would deliver the battery rated capacity in $1 \mathrm{hr}$, and $2 \mathrm{C}$ discharge rate means it will discharge twice as fast in 30 minutes. In this work, 1.5C-rate and 3C-rate were taken into consideration for simulations (Figure 7).

\subsection{Cooling Fan}

Active cooling technologies, that rely on an external device (cooling fan) to enhance the heat transfer. The fan can be used to cool down the battery and to maintain the optimum temperature range for the battery. In which, the rate of fluid flow increases the heat removal rate. At the top of the module, there are inlet and outlet sections where we can mount a cooling fan to force the air for cooling. Adding a properly sized cooling fan to this battery module will force air across the module and allow the greater thermal transfer. The following specifications of the cooling fan (Table 4) can match the battery module configuration.

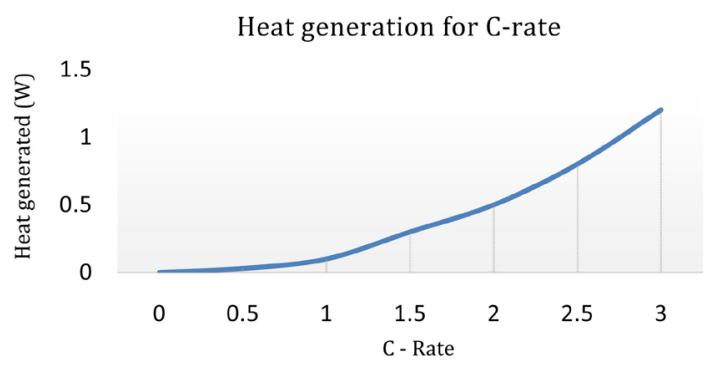

Figure 7. Heat generation for C-rate.

Table 3. Heat generation of the cell.

\begin{tabular}{ccccc}
\hline Distance between the cells & $\begin{array}{c}\text { Discharge } \\
\text { rate }\end{array}$ & $\begin{array}{c}\text { Current of } \\
\text { the cell }(\mathrm{Ah})\end{array}$ & $\begin{array}{c}\text { Heat } \\
\text { generation } \\
\text { per cell }(\mathrm{W})\end{array}$ & $\begin{array}{c}\text { Heat } \\
\text { generation } \\
\text { rate }\left(\mathrm{W} / \mathrm{m}^{3}\right)\end{array}$ \\
\hline \multirow{2}{*}{$1.5 \mathrm{~mm}$} & $1.5 \mathrm{C}$ & 3.12 & 0.3 & 11,000 \\
& 3C & 6.24 & 1.2 & 43,700 \\
& $1.5 \mathrm{C}$ & 3.12 & 0.3 & 10,415 \\
& 3C & 6.24 & 1.2 & 41,652 \\
& $1.5 \mathrm{C}$ & 3.12 & 0.3 & 9921 \\
& 3C & 6.24 & 1.2 & 39,685 \\
\hline
\end{tabular}


Table 4. Cooling fan specifications.

\begin{tabular}{ccc}
\hline & $\begin{array}{c}0.3 \mathrm{~W} / \text { Cell } \\
\text { (Equivalent to } 1.5 \mathrm{C})\end{array}$ & $\begin{array}{c}1.2 \mathrm{~W} / \text { Cell } \\
\text { (Equivalent to 3C) }\end{array}$ \\
\hline Coolant type & Air & Air \\
Dimensions & $60 \times 60 \times 38$ & $60 \times 60 \times 38$ \\
Velocity & 3 to 6 & 6 to 11 \\
Air flow & 40 to 82 & 82 to 142 \\
Rated Voltage & 24 & 24 \\
\hline
\end{tabular}

\subsection{Study}

All the simulations are performed in steady state, as the goal has been to compare the overall performance of the air-cooling method for different flowrates mentioned as $3 \mathrm{~m} / \mathrm{s}$ to $6 \mathrm{~m} / \mathrm{s}$ for $1.5 \mathrm{C}$-rate and $6 \mathrm{~m} / \mathrm{s}$ to $11 \mathrm{~m} / \mathrm{s}$ for 3C-rate. And, to compare the performance by increasing the gaps between the cells from 1.5 $\mathrm{mm}, 2 \mathrm{~mm}$ and $2.5 \mathrm{~mm}$ in the module. As results from the simulations are studied based on certain criteria such as maximum temperature in a module, coolant temperature rise, and the temperature distribution in each cell and modules are compared to each other.

\section{Results and Discussion}

In order to estimate the impact of cells spacing gap ( $1.5 \mathrm{~mm}, 2 \mathrm{~mm}$ and $2.5 \mathrm{~mm})$ and flow rate supplied by fan system, the various configurations have been analyzed for 1C-rate and 3C-rate, corresponding to $0.3 \mathrm{~W}$ and $1.2 \mathrm{~W}$ of heat generation per single cell.

In Figure 8 the temperature maps of the module are reported, for 1C-rate and a set of flow rates; as expected, the hottest cells are in central position, but the difference between hottest and coldest cells ( $\Delta \mathrm{T}$ in the following) do not exceed $4^{\circ} \mathrm{C}$, a good value for an automotive application. At higher flow rates, $5 \mathrm{~m} / \mathrm{s}$ and $6 \mathrm{~m} / \mathrm{s}$, this air cooling is able to perform adequate cells cooling and a good temperatures distribution along the module.

In Figure 9 the same module geometric configuration $(1.5 \mathrm{~mm}$ of air gap between cells) is simulated at a discharge current equal to 3C-rate, for a new set of fan flow rates, starting from $6 \mathrm{~m} / \mathrm{s}$ (in order to compare the results with 1C-rate case) to $11 \mathrm{~m} / \mathrm{s}$.

In this case, the $\Delta \mathrm{T}$ rise noticeably and reaches the value of $9^{\circ} \mathrm{C}$ for the case with an air flow rate of $6 \mathrm{~m} / \mathrm{s}$; with an air flow rate of $11 \mathrm{~m} / \mathrm{s}$ the $\Delta T$ decrease to a value of $6^{\circ} \mathrm{C}$, an optimal value for automotive applications. The $3 \mathrm{C}$-rate is equivalent to $28 \mathrm{~kW}$ of power supplied by the whole battery pack to the electric drive, that is a overall power higher than the average power utilized during "Endurance" Formula Student event. Thus, this case represents a severe thermal test of the cooling system. Obviously, the ambient temperature must be considered for future applications. 

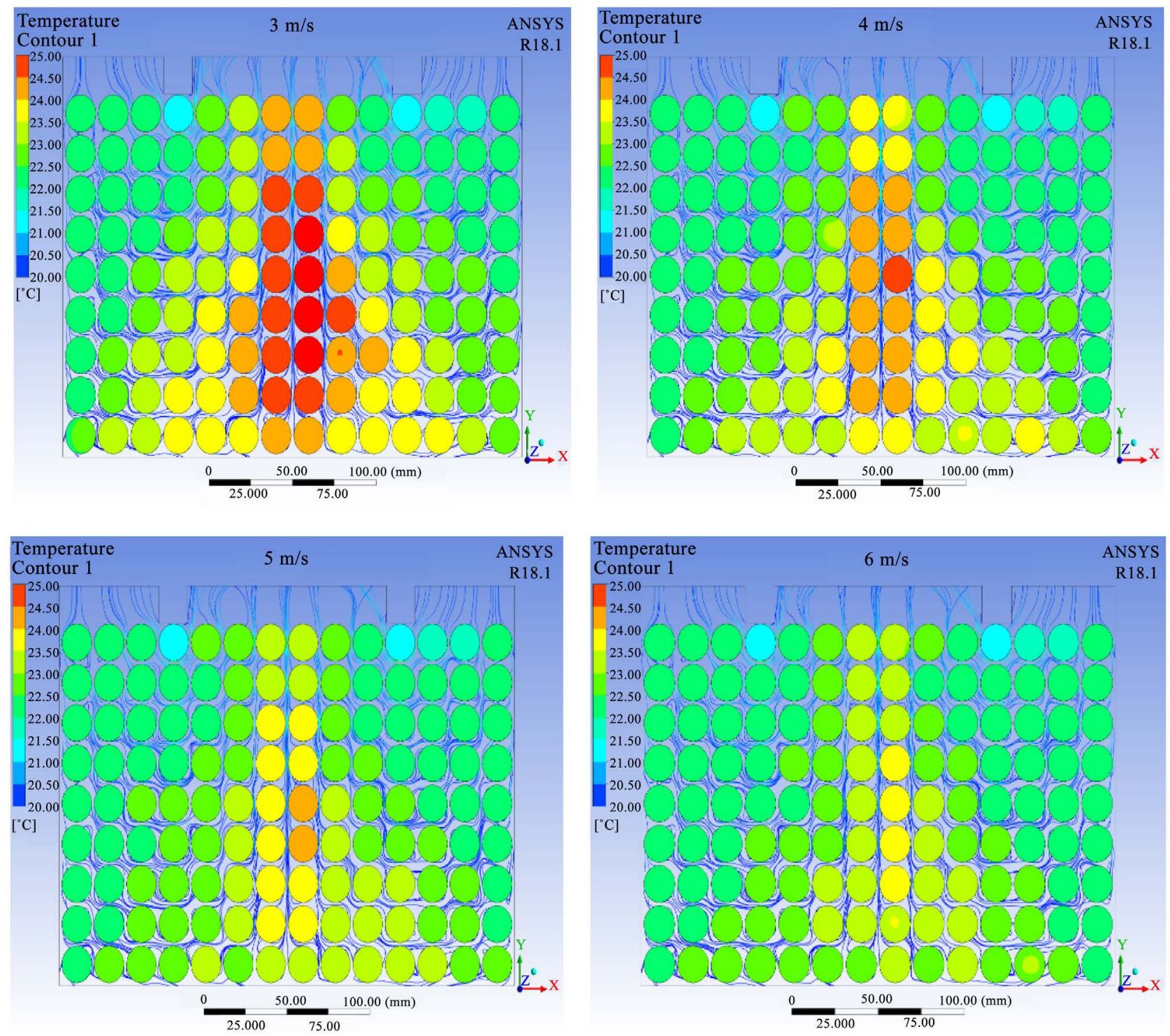

Figure 8. Temperature distribution with air cooling at $3 \mathrm{~m} / \mathrm{s}, 4 \mathrm{~m} / \mathrm{s}, 5 \mathrm{~m} / \mathrm{s}, 6 \mathrm{~m} / \mathrm{s}$ in the $1.5 \mathrm{~mm}$ spacing configuration of 0.3 W/Cell.

In Figure 10 the case of $2 \mathrm{~mm}$ of air gap between cells is simulated and reported for 1C-rate case. The increased air gap reduces the air speed in the stream line between cells and, as consequence; the heat removal is less efficient, without any advantage in air flow friction reduction. Similar consideration can be made by considering Figure 11, where the 3C-rate case with $2 \mathrm{~mm}$ air gap is reported. Thus, it is evident that, in the case with $2 \mathrm{~mm}$ air gap, $\Delta \mathrm{T}$ and number of cells at higher temperatures increase.

In Figure 12 and Figure 13 the results of analysis for $2.5 \mathrm{~mm}$ air gap configuration are reported, and it is evident the confirmation of a sensible reduction of heat removal efficiency.

In general for all the configuration and C-rate considered, it can be seen in the module, that the cell temperature is low near the inlet, and the cell temperature 

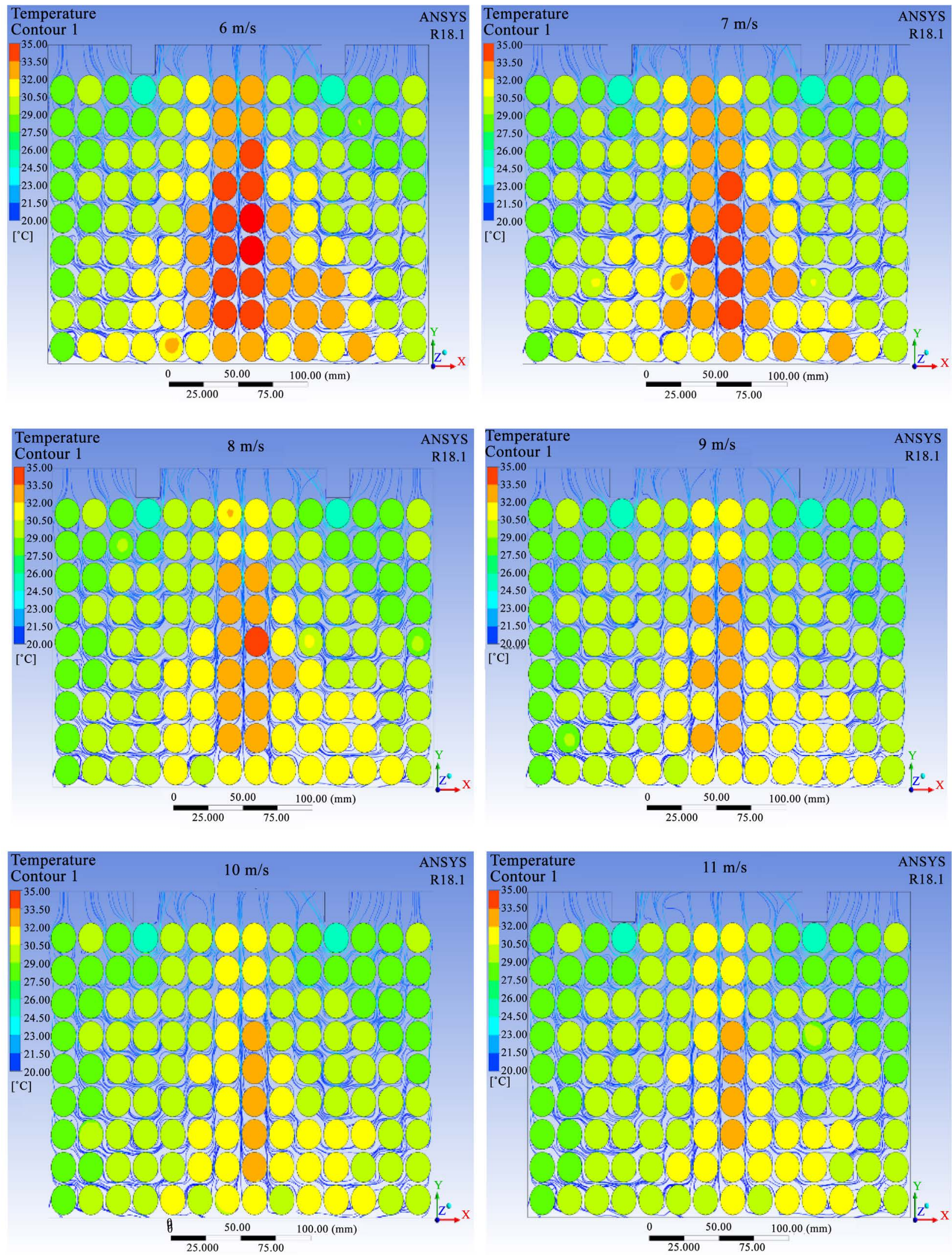

Figure 9. Temperature distribution with air cooling at $6 \mathrm{~m} / \mathrm{s}, 7 \mathrm{~m} / \mathrm{s}, 8 \mathrm{~m} / \mathrm{s}, 9 \mathrm{~m} / \mathrm{s}, 10 \mathrm{~m} / \mathrm{s}, 11 \mathrm{~m} / \mathrm{s}$ in the $1.5 \mathrm{~mm}$ spacing configuration of $1.2 \mathrm{~W} /$ Cell. 

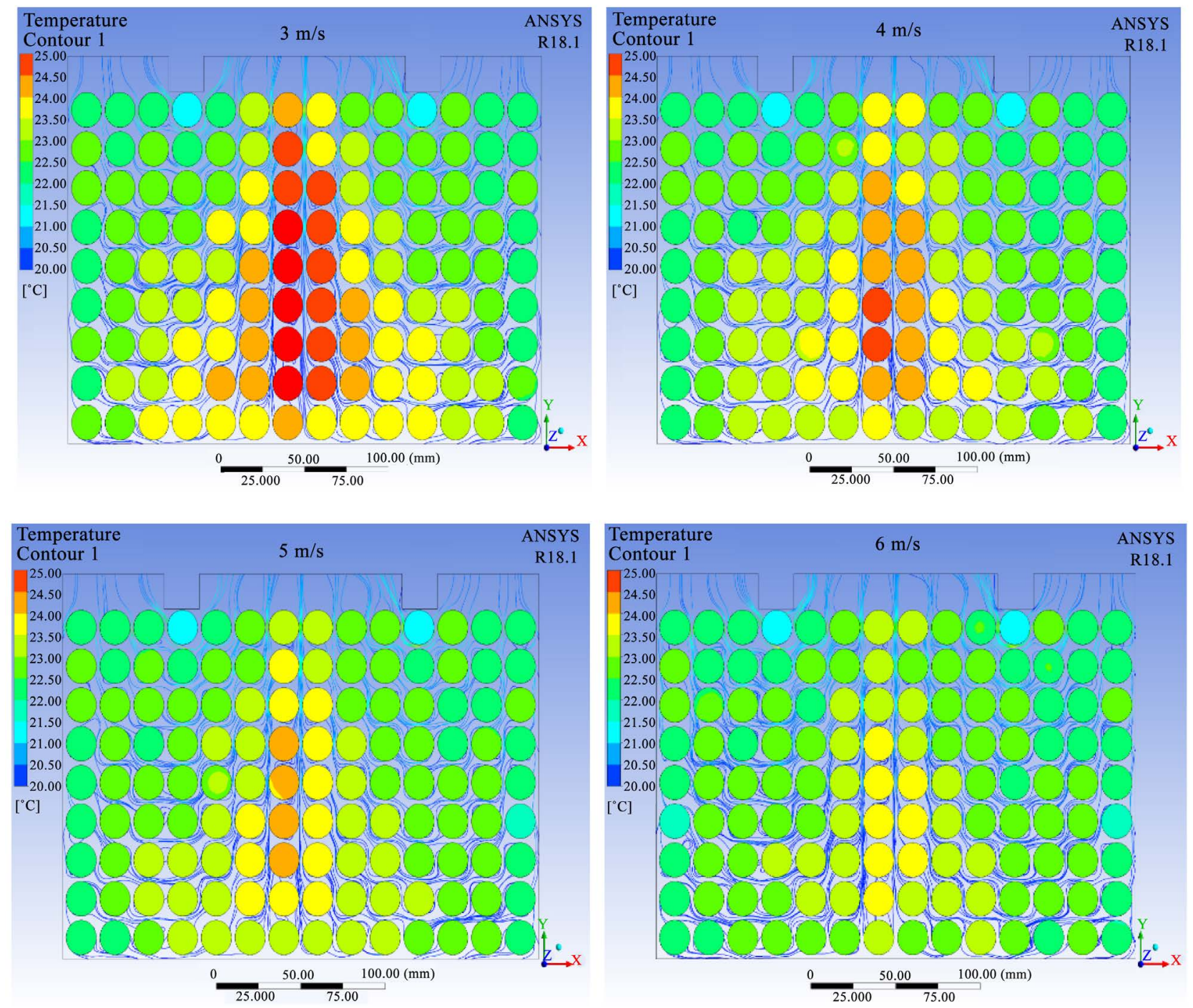

Figure 10. Temperature distribution with air cooling at $3 \mathrm{~m} / \mathrm{s}, 4 \mathrm{~m} / \mathrm{s}, 5 \mathrm{~m} / \mathrm{s}, 6 \mathrm{~m} / \mathrm{s}$ in the $2 \mathrm{~mm}$ spacing configuration of 0.3 W/Cell.

is high in the middle area near to the outlet. It is in the situation when the air flows through the battery surface, which has a higher temperature, it will absorb heat from the cells leading to a gradual increase in the temperature of air from the inlet to outlet. But when we observe the cells at outlet, the cell temperature is little bit low compare with the temperature in the middle area, because it depends on the module layout where both the outlets are placed side by side, in which the air is distributed evenly coming from the two paths absorbs the cell heat at the outlet to reduce the temperature.

\subsection{Influence of Air Flowrate}

As reported in Figure 14 and Figure 15, as the increasing air flowrate, the convective heat transfer in the module will be increased, and then the cell temperatures are going to be reduced. From the figures above, the maximum temperature in 

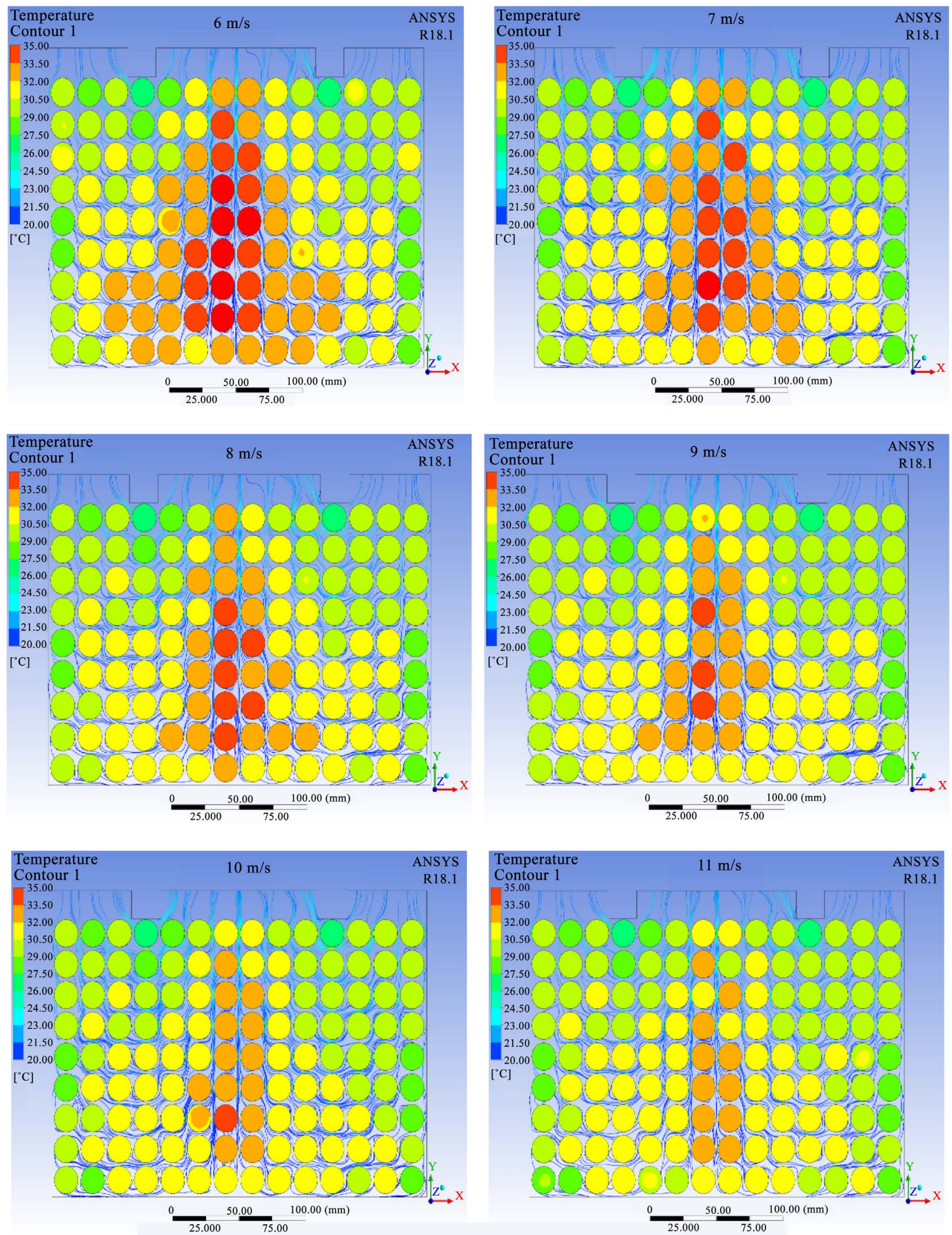

Figure 11. Temperature distribution with air cooling at $6 \mathrm{~m} / \mathrm{s}, 7 \mathrm{~m} / \mathrm{s}, 8 \mathrm{~m} / \mathrm{s}, 9 \mathrm{~m} / \mathrm{s}, 10 \mathrm{~m} / \mathrm{s}, 11 \mathrm{~m} / \mathrm{s}$ in the 2 mm spacing configuration of $1.2 \mathrm{~W} /$ Cell. 

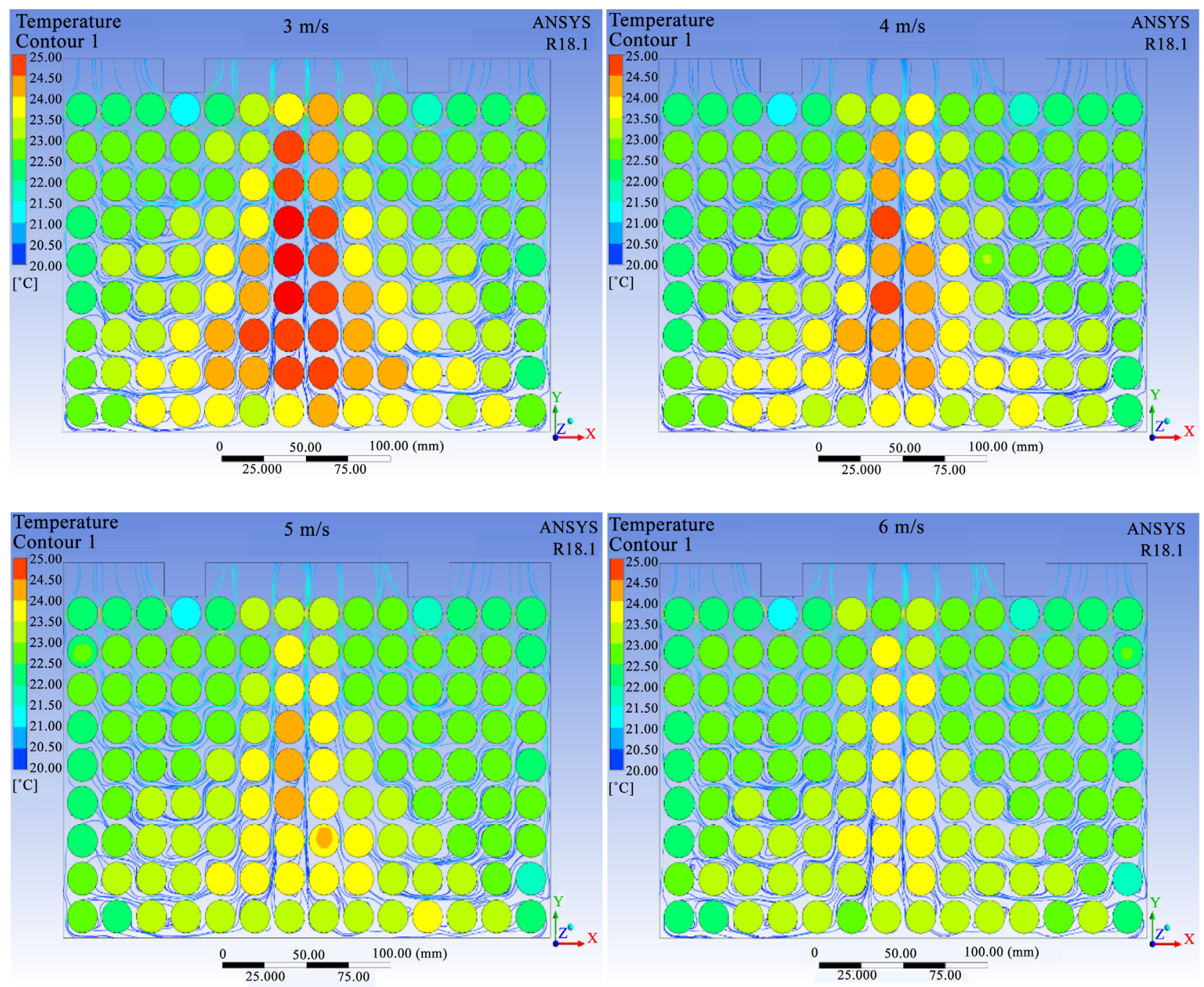

Figure 12. Temperature distribution with air cooling at $3 \mathrm{~m} / \mathrm{s}, 4 \mathrm{~m} / \mathrm{s}, 5 \mathrm{~m} / \mathrm{s}, 6 \mathrm{~m} / \mathrm{s}$ in the $2.5 \mathrm{~mm}$ spacing configuration of 0.3 W/Cell.

the module is slowly decreasing as the air flowrate increases for both $1.5 \mathrm{C}$ and $3 \mathrm{C}$ discharge rates, and same as, the maximum $\Delta \mathrm{T}$ in the module is also reducing. $\Delta \mathrm{T}$ in the $3 \mathrm{C}$ rate module is high at $6 \mathrm{~m} / \mathrm{s}$ which is a problem with air cooling, where the amount of coolant is needed. For what when we observed at 11 $\mathrm{m} / \mathrm{s} \Delta \mathrm{T}$ is also reduced. In this method, when the heat is increasing at $3 \mathrm{C}$-rate, while we increase the flowrate in the module, it requires additional power to get the maximum flowrate. But improving thermal performance by increasing the air flowrate in the module will significantly increase energy consumption.

\subsection{Influence of Spacing between the Cells}

It is seen that the maximum temperature in the module is rapidly increasing as the gap increases between the cells, which means the thermal performance is deteriorated. As reported in Figure 16, $\Delta \mathrm{T}$ in the module of 1.5C-rate is slowly decreasing as the gap increases, but it is not the same case when the heat 

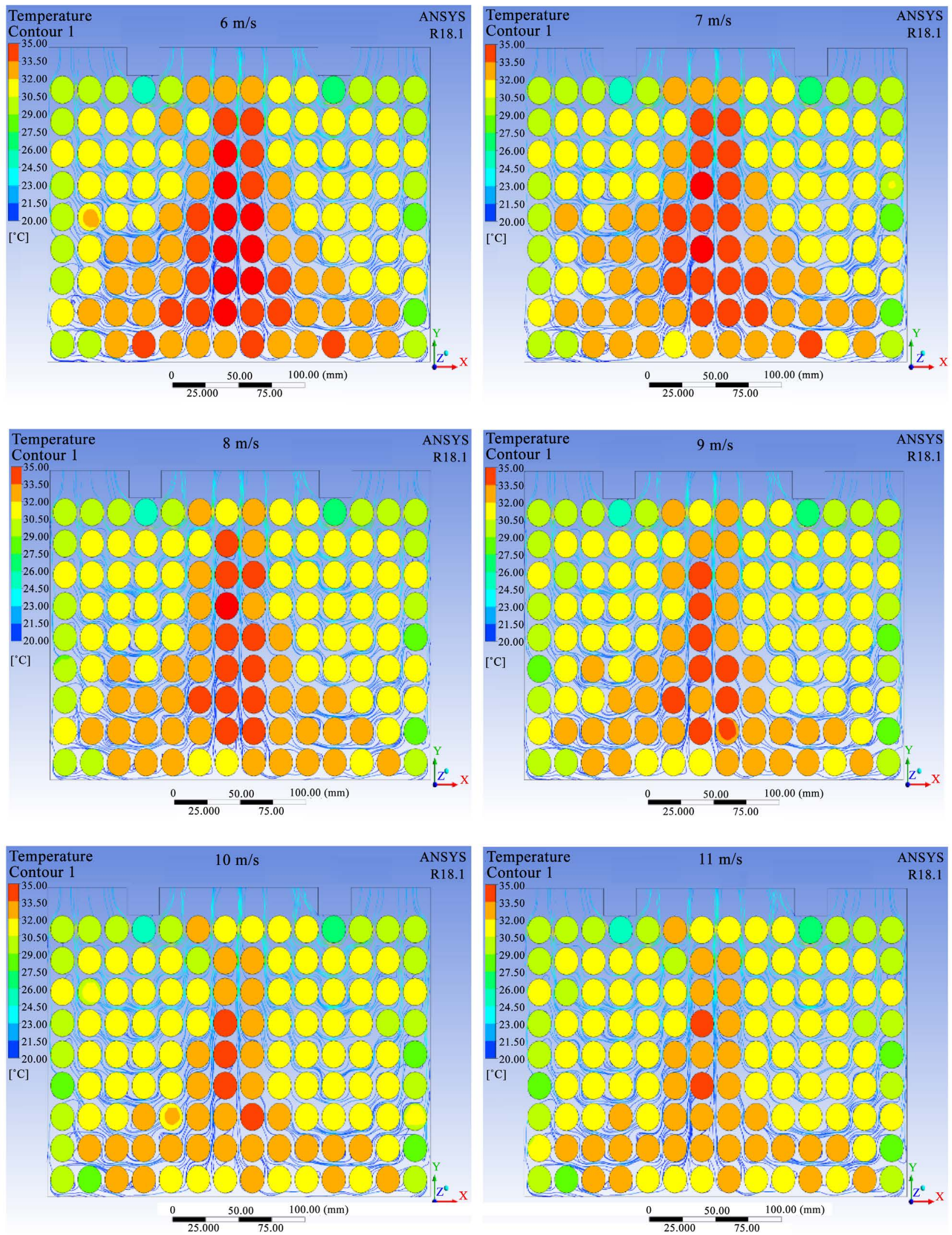

Figure 13. Temperature distribution with air cooling at $6 \mathrm{~m} / \mathrm{s}, 7 \mathrm{~m} / \mathrm{s}, 8 \mathrm{~m} / \mathrm{s}, 9 \mathrm{~m} / \mathrm{s}, 10 \mathrm{~m} / \mathrm{s}, 11 \mathrm{~m} / \mathrm{s}$ in the $2.5 \mathrm{~mm}$ spacing configuration of $1.2 \mathrm{~W} /$ Cell. 
$1.5 \mathrm{C}$ - Rate

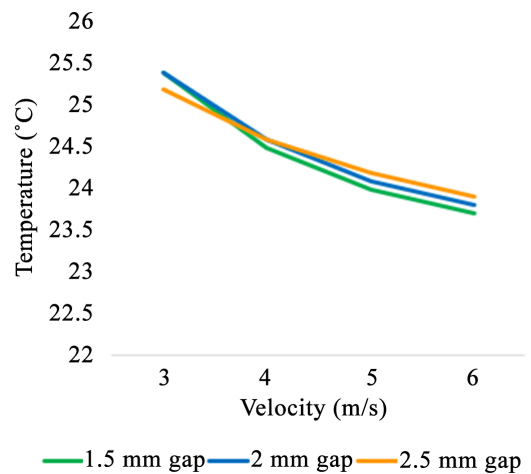

3C - Rate

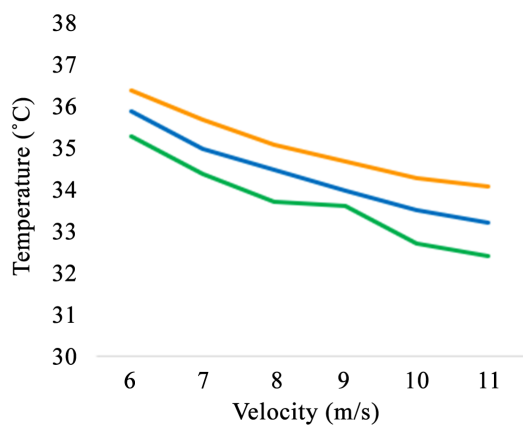

Figure 14. Comparison of maximum temperature for three configurations with different Flowrates.

$1.5 \mathrm{C}$ - Rate

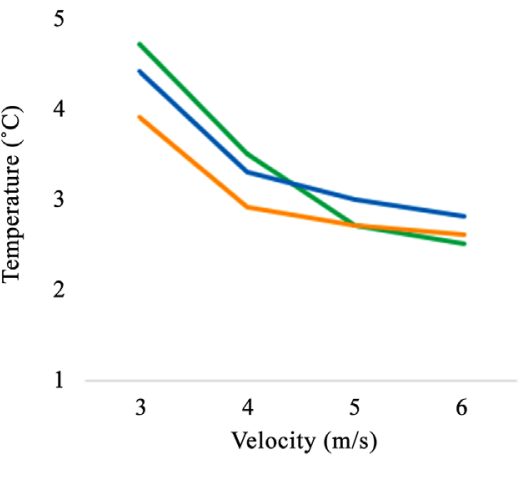

$-1.5 \mathrm{~mm}$ gap $-2 \mathrm{~mm}$ gap $-2.5 \mathrm{~mm}$ gap
3C - Rate

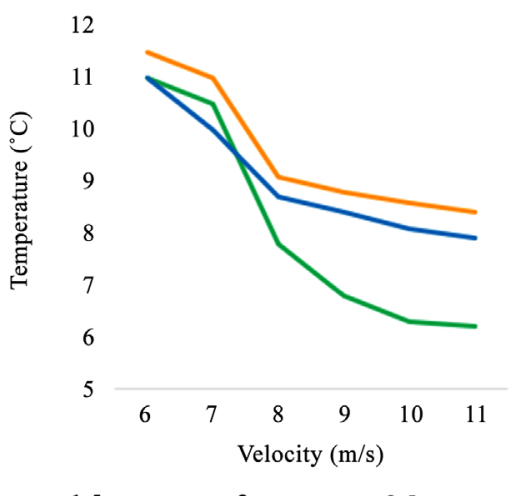

Figure 15. Comparison of temperature difference for three configurations with different flowrates.
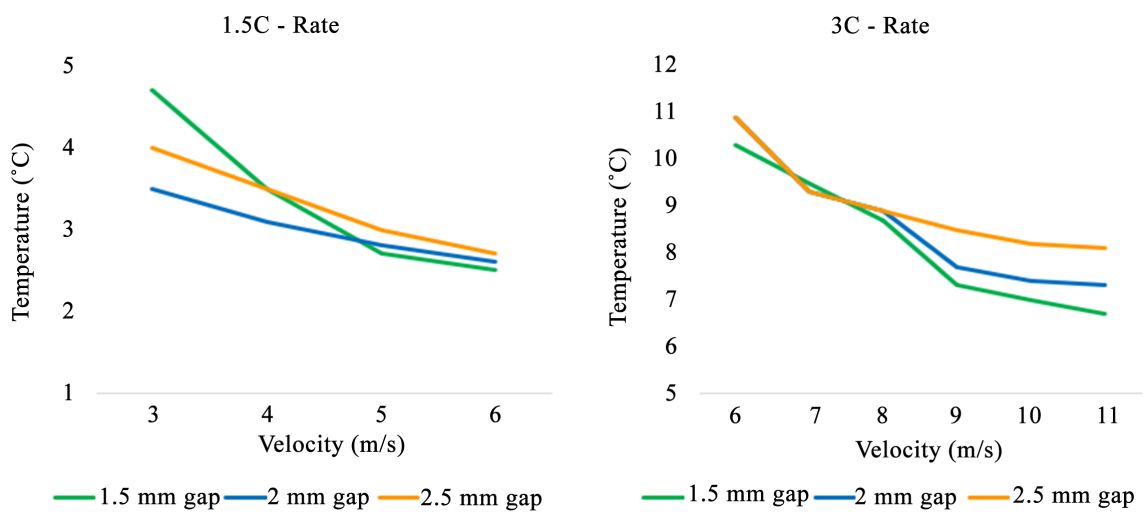

Figure 16. Comparison of coolant temperature difference for three configurations with different flowrates.

increases at 3C-rate, $\Delta \mathrm{T}$ is gradually increasing when the gap increases. It is found that the spacing significantly affects the temperature uniformity. From the increased air flowrates with the three spacing sizes of modules, it is observed that the flowrate increases at the inlet and decreases near the outlet as the gap in- 
creases. Thus, the uneven temperature distribution of the air flowrate leads to a higher temperature difference in the case of $2 \mathrm{~mm}$ and $2.5 \mathrm{~mm}$ distance between the cells.

When the gap decreases, the uniformity of the air flowrate between the cells is improved, which can help to reduce the temperature difference of the battery pack and also increase the convective heat transfer coefficient on the surface of the cells which reduce the cell temperatures. This work suggests the optimum spacing for the lowest maximum temperatures. And the smaller spacing would be preferred because of the packaging constraints of the battery systems in vehicle.

\section{Conclusions}

The main objective of this thesis work is to study the cooling performance of the air-cooling battery thermal management system specific to 18,650 Li-ion cells. Typical cases are employed on the battery configuration to explore the influences of increasing space between the cells with different flowrates. The comparison of all the simulations at $1.5 \mathrm{C}$ - rate shows that the configuration of $1.5 \mathrm{~mm}$ spacing with the velocity of $6 \mathrm{~m} / \mathrm{s}$ is giving the better result of maximum temperature is $23.7^{\circ} \mathrm{C}$ and the maximum temperature difference in the module is $2.5^{\circ} \mathrm{C}$ (see Figure 17).

For the other two configurations of distance $2 \mathrm{~mm} \& 2.5 \mathrm{~mm}$ spacing, the maximum temperature and the temperature difference are increasing even the heat value is less compared with the other module of $1.5 \mathrm{~mm}$ distance by increasing the gap between the cells. At 3C-rate, the configuration of $1.5 \mathrm{~mm}$ spacing with a velocity of $11 \mathrm{~m} / \mathrm{s}$ is giving a better result that the maximum temperature is $32.45^{\circ} \mathrm{C}$, and the maximum temperature difference in the module is $6.2^{\circ} \mathrm{C}$. For the other two configurations of distance $2 \mathrm{~mm} \& 2.5 \mathrm{~mm}$ spacing, the maximum temperature and the temperature difference are increasing as same as the condition above. As the air flowrate increases, the maximum temperature and temperature difference of the battery pack is reduced, but it consumes more power to maintain the flowrate. As the cell spacings increase, the maximum temperature and temperature difference of the battery pack are both increased effectively. From the above simulations, it can be concluded that the cooling performance of the system can be improved by keeping the optimum spacing between the cells and increasing the optimum flowrate while maintaining less power consumption are the effective approaches for this configuration. This approach can reduce the maximum temperature and temperature difference in the configuration of both $1.5 \mathrm{C} \& 3 \mathrm{C}$ discharge rates. Finally, the car competes in endurance event which is part of the competition where the car has to drive 22 $\mathrm{km}$ as fast as possible. This event is the most critical part of the competition for overheating the battery and testing the performance. This battery cooling system in the formula student car can keep the battery temperature within the maximum operating range and it can compete in this event without overheating the battery cells more than $35^{\circ} \mathrm{C}$ while the driver uses the maximum heat capacity. 

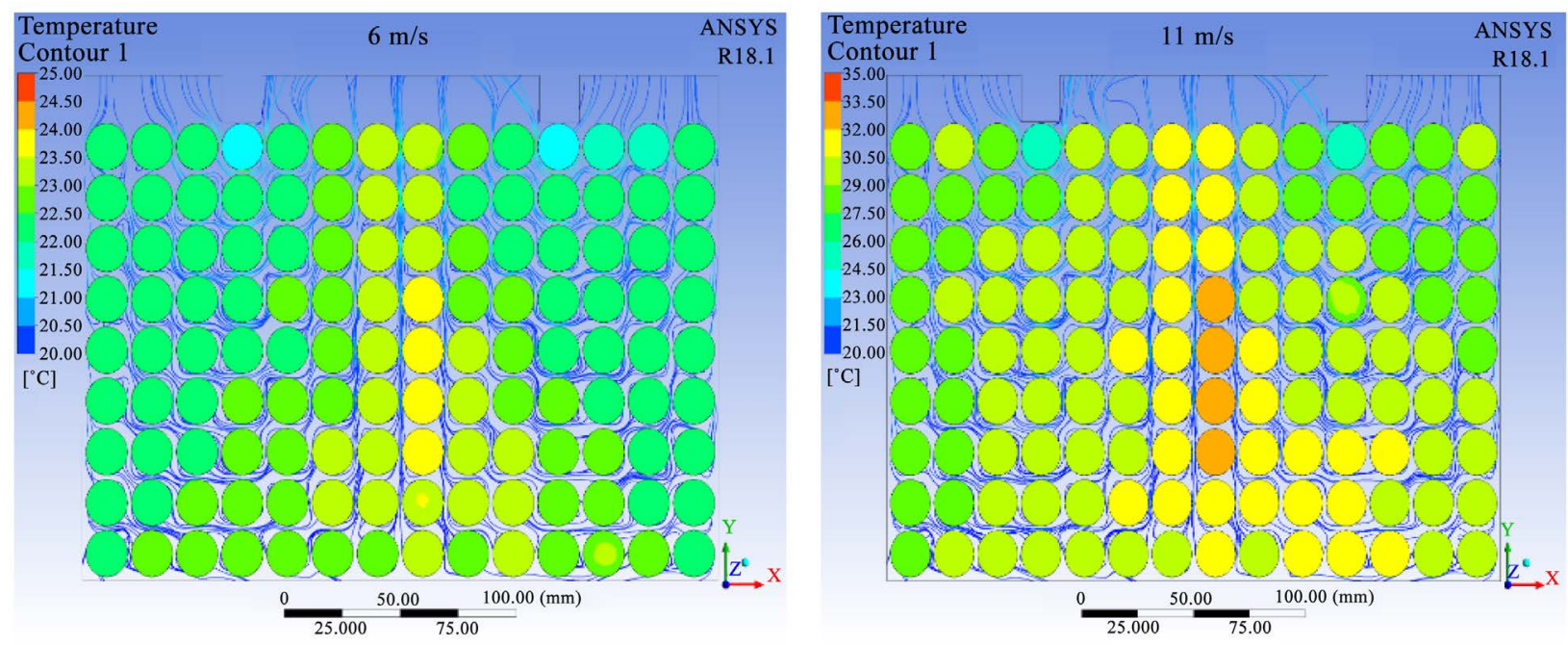

Figure 17. Temperature distribution at $6 \mathrm{~m} / \mathrm{s} \& 11 \mathrm{~m} / \mathrm{s}$ on $1.5 \mathrm{~mm}$ spacing configuration of $0.3 \mathrm{~W} /$ Cell \& $1.2 \mathrm{~W} /$ Cell.
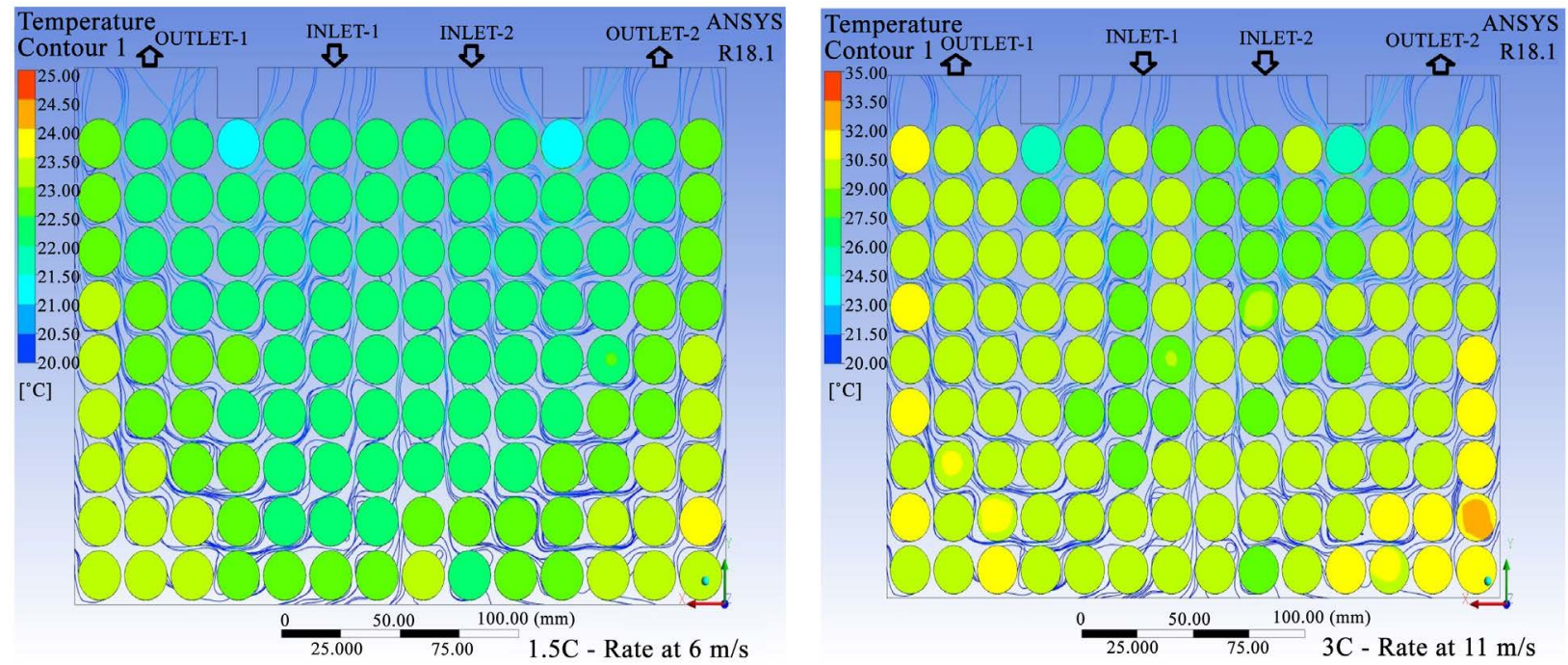

Figure 18. Inverted flow for $0.3 \mathrm{~W} /$ cell \& $1.2 \mathrm{~W} /$ Cell modules with the flowrate of $6 \mathrm{~m} / \mathrm{s} \& 11 \mathrm{~m} / \mathrm{s}$.

\section{Future Work}

In this module, we changed the paths of inlet $\&$ outlet like inverted the flow for $1.5 \mathrm{C} \& 3 \mathrm{C}$ rate module with the optimal velocity of $6 \& 11 \mathrm{~m} / \mathrm{s}$. This approach reduced the maximum temperature and temperature difference in the module compare with the previous normal flowrate modules (see Figure 18). This approach can also be used for future work for better results.

\section{Conflicts of Interest}

The authors declare no conflicts of interest regarding the publication of this paper.

\section{References}

[1] Chen, K., Li, Z.Y., Chen, Y.M., Long S.M. and Hou, J.S. (2017) Design of Parallel 
Air-Cooled Battery Thermal Management System through Numerical Study. Energies, 10, 1677. https://doi.org/10.3390/en10101677

[2] Peng, X.B., Cui, X.J., Liao, X.P. and Garg, A. (2020) A Thermal Investigation and Optimization of an Air-Cooled Lithium-Ion Battery Pack. Energies, 13, 2956. https://doi.org/10.3390/en13112956

[3] Ismail, N.H.F., et al. (2014) Simplified Heat Generation Model for Lithium Ion Battery Used in Electric Vehicle. 5 th International Conference on Mechatronics (ICOM13), Kuala Lumpur, Malaysia, 2-4 July 2013, 6 p. https://doi.org/10.1088/1757-899X/53/1/012014

[4] Mahamud, R. and Park, C. (2011) Reciprocating Air Flow for Li-Ion Battery Thermal Management to Improve Temperature Uniformity. Journal of Power Sources, 196, 5685-5696. https://doi.org/10.1016/j.jpowsour.2011.02.076

[5] Lu, Z., Meng, X.Z., Wei, L.C., Hu, W.Y., Zhang, L.Y. and Jin, L.W. (2016) Thermal Management of Densely-Packed EV Battery with Forced Air Cooling Strategies. Energy Procedia, 88, 682-688. https://doi.org/10.1016/j.egypro.2016.06.098

[6] Rugh, J.P., Peseran, A. and Smith, K. (2011) Electric Vehicle Battery Thermal Issues and Thermal Management Techniques. NREL/PR 5400-52818.

https://www.nrel.gov/docs/fy13osti/52818.pdf

[7] Abdul-Quadir, Y., et al. (2014) Heat Generation in High Power Prismatic Li-Ion Battery Cell with $\mathrm{LiMnNiCoO}_{2}$ Cathode Material. Energy Resources, 38, 1424-1437. https://doi.org/10.1002/er.3156

[8] Wang, T., Tseng, K., Zhao, J. and Wei, Z. (2014) Thermal Investigation of Lithium-Ion Battery Module with Different Cell Arrangement and Forced Air-Cooling Strategies. Applied Energy, 134, 229-238. https://doi.org/10.1016/j.apenergy.2014.08.013

[9] Rajib Mahamud, C.P. (2011) Reciprocating Air Flow for LI-Ion Battery Thermal Management to Improve Temperature Uniformity. Journal of Power Sources, 196, 5685-5696. https://doi.org/10.1016/j.jpowsour.2011.02.076

[10] Liu, H., Wei, Z., He, W. and Zhaoa, J. (2017) Thermal Issues about Li-Ion Batteries and Recent Progress in Battery Thermal Management Systems: A Review. Energy Conversion and Management, 150, 304-330.

https://doi.org/10.1016/j.enconman.2017.08.016 